\title{
Analysis of Students' Academic Performance in General English in Kwara State College of Education (Tech.), Lafiagi, Nigeria
}

\author{
Shola Sunday Olanipekun \\ General Studies Education Department, College of Education (Tech.), Lafiagi, Nigeria \\ Email: sholexofafrica@gmail.com
}

Received 29 June 2015; accepted 15 July 2015; published 20 July 2015

Copyright (C) 2015 by author and OALib.

This work is licensed under the Creative Commons Attribution International License (CC BY). http://creativecommons.org/licenses/by/4.0/

(c) (i) Open Access

\section{Abstract}

This paper employed a descriptive survey study of students' academic performance in General English 1V (GSE 221) of 2012/2013 academic session in the Kwara State College of Education (Tech.) Lafiagi, Nigeria. Two hundred and eighty-six students were sampled for the study. Profoma was used to collect data. Frequency count and percentage, frequency bar chart, $t$-test and descriptive statistics were used to analyze the data collected. The results showed that students' academic performance in General English was awfully poor. Findings on gender depicted that better academic performance in English was not gender specific. The paper concluded that language studies should be enhanced if students' effective communication and good academic performance must be achieved. Recommendations were suggested at the end of the study.

\section{Keywords}

Students' Academic Performance, General English and Gender

Subject Areas: Education

\section{Introduction}

Some scholars have given credent to the notion that English language is very crucial to the Nigeria education system since it is not only the medium of instruction especially at the upper primary, secondary and tertiary level of education but also the language of text-books [1]. Thus, it is through the vehicle of English language that student accesses knowledge in other subject areas. Due to this tendency, it has been asserted that there has been a great appeal of the mastering of the English language to enhance better academic performance [2]. Yet, being assimilated into the English culture is not synonymous with the mastering of the language.

On the rostrum of students' academic performance, it has been aptly unfolded that students' academic per- 
formance is the scholastic standing of a student at a given moment [3]. This is also used to describe how an individual is able to demonstrate his or her intellectual abilities. The term "scholastic standing" is explained as the grades obtain in a course or group of courses taken [4] and [5].

Though the hegemony of English language in the academic world of knowledge has attracted researchers to publish their valuable findings in English international databases [6], yet, it has been observed that there is indeed a lot wrong with the performance in English even among the University students and graduates for that matter [7]. Another scholar confirmed that even among the Arab, students performed poorly in General English which compounded their reading comprehension difficulties [8]. This is further buttressed in the yearly released WASSCE based on English language of 1990 to 1998 which are evidences of this sad state of affairs and the percentage of those that got grades A1-C6 as seen in Table 1.

Notwithstanding, all stakeholders in the Nigeria's system (parents, guardians, teachers, counselor, etc.) are so much concerned about students' academic performance in relation to academic standard [10]. This is as a result of the notion that academic performance is a virile instrument to the national development of any nation but it is pathetic to know that students' academic performance in Nigeria is not encouraging and most especially in English Language.

This shameful failure is axiomatically noted in the public's unhappiness which becomes more prominent following the annual release of the West Africa Senior School Certificate Examination results, since the student outcomes do not match the government and parental investments both at the senior secondary schools and tertiary institutions [11]. Nevertheless, it is obvious that students' academic performance in English Language is abysmally low.

It is pathetic therefore to infer at this juncture that with political and social upsurge, economic instability and the implication of government inability to adequately supply needed funds, qualified teachers and infrastructures to cope with the increase of students' enrolments in schools, the qualitative standard of learning outcome by both undergraduates and graduates and their counter-parts in various Colleges of Education in the country today based on English language have created a vortex of "sicky" national concern.

Worsening great cases of examination malpractice, indiscipline, cultism, and high failure rates of the students' populace have led to the loss of public confidence in the school. The general verdict is that there is growing loss of confidence in the system with appalling academic performance of students.

At this juncture, one could seek to know in relation to students' academic performance whether sex factor also plays an important role [12]. Gender is an ascribed attribute that differentiates feminine from masculine socially. Gender is a related term that stresses the roles and responsibilities of males and females [13]. In this sense, the so called "ascribed role" has made some students to have English phobia, especially those in the sciences and some male students generally on the basis of orientation. They fear anything in form of literature and writing.

It is common to hear a male science student who prefers studying all the sciences in chemistry concept and the nature and meaning of science in Physics says "I don't like English language as a subject and presently I just registered for it in my course form because it is compulsory". Again, it is believed that female students could perform better than their male counterparts in English language. This is as a result of the notion that female students

Table 1. Performance of candidates in English language in SSCE 1990-1998.

\begin{tabular}{ccc}
\hline Years & No. of candidates & A1-C6\% \\
\hline 1990 & 197,012 & 6.2 \\
1991 & 299,323 & 10.2 \\
1992 & 369,964 & 11.4 \\
1993 & $5,010,491$ & 13.3 \\
1994 & 524,282 & 14.3 \\
1995 & 464,270 & 12.4 \\
1996 & 516,196 & 11.3 \\
\hline
\end{tabular}

Source: [9]. 
like reading articles, newspapers, novels, and so on which invariably has positive influence on their performance.

To this effect, studies have shown that there exists distinction between boys and girls in their academic performance based on gender [14]. The reason revealed that as for gender, it was seen that girls tended to have a higher emotional intelligence level. The findings of Agarwal, V.R. (1983) [15] also tossed the same line with that of Battal, O. (2012) who disclosed that females showed a higher reading ability and culture in their academic performance than the males. However, male students performed better than female students when the teaching-learning process involved reading and verbal instructions [16].

It is therefore obvious from the foregoing that, apart from the notion that gender has been found to play an importance role in influencing students' academic performance in General English in tertiary institutions in Nigeria; it is also plausible to note that academic performance of students in General English is nothing to write home about and this is linked to their low performance and proficiency in English language [17]. No wonder it is no more a hidden fact in Nigeria that students admitted into our universities and other tertiary institutions are quite deficient in the use of English.

\section{Research Questions}

1) Is there any significant difference in the students' academic performance based on gender in General English?

2) Is there any significant relationship between passed students' mean scores based on gender in General English in Colleges of Education in Kwara State?

\section{Research Hypotheses}

$\mathbf{H o}_{1}$. There is no significant difference in the students' academic performance based on gender.

$\mathbf{H o}_{2}$. There is no significant relationship between passed students' mean scores based on gender in General English in Colleges of Education in Kwara State.

\section{Research Methodology}

This research work employed descriptive survey method where students' scores in General English 1V (GSE 221) 2012/2013 academic session were collected and analyzed for the purpose of the study. The sample population comprises of students from the College of Education (Tech.) Lafiagi in Kwara State. This is used to find out and to obtain information and to gather understanding of the present condition [18]. Pro-foma was used to collect students' scores with a total number of two hundred and eighty six students. One hundred and thirteen of all the overall students were used to find out students' academic performance based on gender.

The researchers with the permission of the Head of the Department, General Studies Education Department in the College of Education (Tech.) Lafiagi, Kwara State Nigeria collected the results of students in General Studies based on General English 1V. The General English results under General Studies Education Department have also gone for moderation under various distinctive higher institutions in the country before being released which made the instruments valid and reliable for this research work.

Research questions and research hypotheses were tested using Frequency count and percentage, T-test and Descriptive statistics.

\section{Findings}

It is therefore plausible for us to infer at this juncture that analysis of students' academic performance in English language in Colleges of Education in Nigeria is connected with the following:

1) Students' academic performance is awfully poor and shameful based on the findings in Table 2 and Figure 1.

2) There is significant difference in the students' academic performance based on gender in English language as seen in Table 3 since the $t_{\text {cal }}$ is greater than the $t_{\text {tab. }}$ in view of this, research question 1 is therefore answered and the research hypothesis 1 thus rejected.

3) Inference on Table 4 and Table 5 would be that good performance in English language is not gender specific and this therefore answered the second research question and yet the second research hypothesis rejected. 


\section{Frequency}

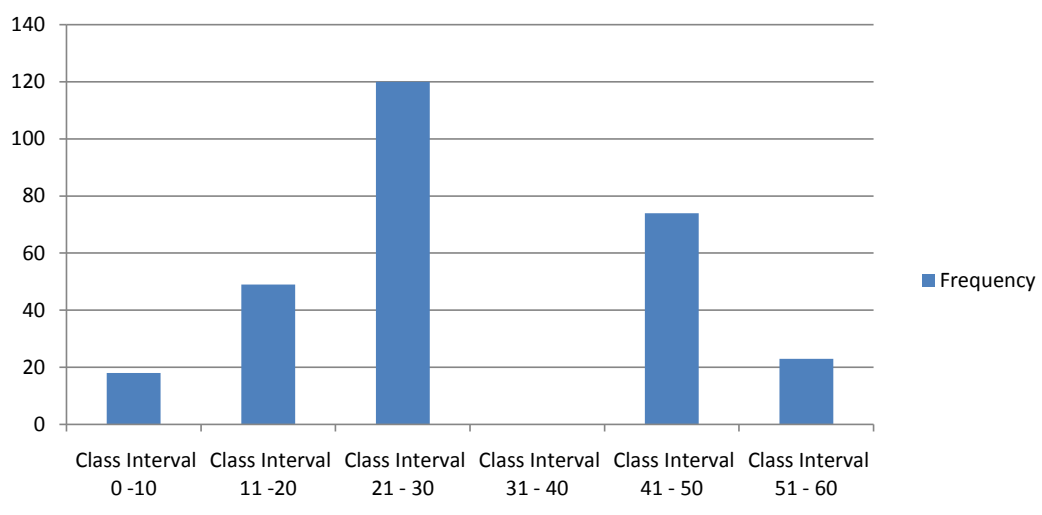

Figure 1. Graphical representation of students' academic performance in General English.

Table 2. Frequency count and percentage’s table on students' academic performance in General English.

\begin{tabular}{ccc}
\hline Class interval & Frequency \\
\hline $1-10$ & 18 \\
$11-20$ & 49 \\
$21-30$ & 120 \\
$31-40$ & 0 \\
$41-50$ & 74 \\
$51-60$ & 23 \\
\hline
\end{tabular}

Table 3. T-test table of all the sample students in General English based on gender.

\begin{tabular}{lcccccc} 
& Mean & Std. dev & Std. error mean & $\mathrm{t}_{\text {cal }}$ & $\mathrm{t}_{\mathrm{tab}}$ & $\mathrm{Df}$ \\
\hline Male and female & -4.49558 & 19.19409 & 1.80563 & 2.490 & 1.665 & 112 \\
\hline
\end{tabular}

Sig. at 0.05 .

Table 4. Mean scores of all the sample students in General English based on gender.

\begin{tabular}{ccccc}
\hline & Mean & $\mathrm{N}$ & Std. dev. & Std. error mean \\
\hline Male & 30.0796 & 113 & 12.73924 & 1.19841 \\
Female & 34.5752 & 113 & 13.45482 & 1.26572 \\
\hline
\end{tabular}

Table 5. Mean scores of the passed group students based on gender.

\begin{tabular}{cccccc}
\hline & N & Minimum & Maximum & Mean & Std. dev. \\
\hline Males & 67 & 40.00 & 60.00 & 47.6269 & 5.06574 \\
Females & 41 & 40.00 & 60.00 & 47.4634 & 4.85849 \\
Valid N (listwise) & 41 & & & & \\
\hline
\end{tabular}

\section{Discussion of findings}

These scholars [19] \& [20] opined that students’ academic performance is one of the current educational prob- 
lems of public interest based on poor level of student's academic performance especially in public examination and at schools and various higher institutions in which English Language is not an exemption. They [21] gave credent to this when they averred that the problem of under achievement among school children has persisted in many subjects areas such as English language. Yet, proficiency in English language is essential not only for academic success alone but to perform in life as various individuals [22].

In this sense, the findings of this research work corroborate with the above assertion. It is therefore plausible to infer at this juncture to the results in Table 2 and Figure 1 where many students wattle between the classes intervals of 21 - 30 indicating the deteriorating level of students' academic performance in English language in Colleges of Education in Nigeria. It is thus obvious that in some tertiary institutions, the academic performance of students in General English is nothing to write home about and this may be linked to their low performance and proficiency in English language right from their secondary school days with poor background.

It is thus evident from the ongoing that performance in English is in crisis in Nigeria and this may also be connected to poor reading habit of most Nigerian students right from their secondary school which further linger till they get to post-secondary school levels. No wonder it was averred that poor performance of students in English Language may be due to poor attitude of teachers, unavailability of instructional materials, poor policy implementation, inadequacies in the English Language curriculum and so on [23].

The findings of this research work further support some many other literatures on the basic disposition of females outperforming their males in English Language. This is affirmed by the results in Table 4 where the mean scores of the females were higher than that of males. Thus, females did better in General English and in anything literature than their male counterparts.

Thus, the research work of Karthigeyen, K. et al. (2012) [24] agreed with the findings above. In their study of academic performance of students in English Language from gender lens in India, they made it known that the performance of the girls is higher than that of the boys. They indicated a significant difference in the performance of both boys and girls. In relation to investigation on gender difference in students' academic performance of girls and boys in schools with to English language in New Zealand; the study which employed a large sample of 5300 pupils showed that performance of girls in English Language was significantly higher than that of boys both in term of mean curriculum coverage and examination's learning outcomes. The result however showed that the boys achieved significantly better results than the girls in mathematics [25]. Thus, boys other than girls are slow started at literacy and English Language subject [26].

However, some findings have revealed that male students perform better than the females in English Language which made findings on gender in English language controversial. And this research work further confirmed this because based on the passed group in English, the males outclass their females [27]. This on physically challenge students keenly noted that male students performed better than their females [28]. Some findings also agreed with the notion of Ademokoya, J.A. (2007) [27] since male students also outclass their females in English Language on the basis of students' entry qualification in English Language in Colleges of Education in Nigeria.

It is therefore expedient for us to say that it is very difficult to use these findings alone to conclude that female students will forever outclass their males or vice versa in English Language or in General English. This study did not explore the roles of family, home background, childbearing, and environmental factors on students' academic performance. This could be a task for another research work.

On students' academic performance in English, while quoting the Chief Examiner for WASSCE in English language reported that the performance of candidates was awfully poor which further solidified the earlier argument in this research paper on the woeful academic performance of students in English language or General English in Colleges of Education in Nigeria [29]. Yet, it has been averred that communicative competence in English language is a factor to academic excellence and performance of students in this part of the world.

\section{Conclusion}

Academic performance of students in General English in College of Education (T.) Lafiagi is horrifying and grotesque. To this effect, it is safe to say that students are not faring well in English with naïve and horrid proficiency in English language. Findings on gender showed that good academic performance in General English may not be gender specific since different researchers have sustained nuances based on their findings as regards gender effect on students' academic performance in which the findings of this research are not equally an exemption. 


\section{Recommendations}

1) English class should not be over-crowded by students. As stipulated by the National Commission for Colleges of Education (2012) an English teacher should not teach more than twenty-five students at a time in class [30]. This will help in the rescue of poor academic performance in English Language. For this to be properly implemented, government should be ready to increase the work force by employing more competent English teachers according to the ratio of the students in the school.

2) Both the males and females in English class should be treated equally in any English class since according to the findings of this research work; one cannot use the performance of one gender to judge the other.

3) Students should be encouraged to read literatures: this will not only avail them the opportunity to attend to certain values and attitudes but to also improve their language proficiency and competence in English language.

\section{References}

[1] Aina, J.K. and Olanipekun, S.S. (2014) The Influence of English Language on Students' Academic Performance in Physics in Colleges of Education. Asian Academic Research Journal of Social Science and Humanities, 1, 271-281.

[2] Attarn, A. (2014) Study of Meta Discourse in ESP Article: A Comparison of English Articles Written by Iranian and English Native Speakers. International Journal of Learning, Teaching and Educational Research, 5, 63-71.

[3] Adeyemi, T.O. (2008) Predictive Students' Performance in Senior Secondary Certificate Examinations from Performance in Junior Secondary Certificate Examination in Ondo State, Nigeria. Journal of Humanity and Social Sciences, 3, 26-36.

[4] Daniel, S.M. and Schouten, J. (1970) Education in Europe: The Screening of Students, Problems of Assessment and Prediction of Academic Performance. Council for Cultural Co-Operation of the Council of Europe. George Harrap Co. Ltd., London.

[5] Owoyemi, N. (2000) Moderation and Standardization of Continuous and Terminal Assessment Scores in Junior Secondary School Certificate Examination and Primary School Learning Certificate Assessment. Paper Delivered at the Senior Staff Seminar, Ministry of Education, Ado-Ekiti.

[6] Flowerdew, J. (1999) Problems in Writing for Scholarly Publication in English: The Case of Hong Kong. Journal of Second Language Writing, 17, 243-364. http://dx.doi.org/10.1016/S1060-3743(99)80116-7

[7] Adesanoye, F.A. (1994) Tertiary English. In: Samuel, O.A. and Adesanoye, F.A., Eds., Language and Polity. Essay on Language and Society in Africa. Sam Bookman Educational, Ibadan, Nigeria.

[8] Djihed, A. (2013) Investigating the Reading Difficulties of Algerian EST Student with Regards to Their General English Knowledge. Arab World English Journal, 4, 203-212.

[9] Federal Government of Nigeria (2006) Comprehensive Education Analysis Project (CEAP). A Project Submitted to Federal Ministry of Education, Abuja.

[10] Akomolafe, M.J. and Olorunfemi-Olabisi, F.A. (2011) The Input of Family Type on Secondary School Students' Academic Performance in Ondo State, Nigeria. European Journal of Educational Studies, 3, 481-487.

[11] Babatunde, S.T. (2002) The State of English language in Nigeria. In: Lawal, A., Isingo-Abanihe, I. and Ohia, I.N., Eds., Perspectives on Applied Linguistic in Language and Literature, Horden Publishers (Nig.) Ltd., Ibadan.

[12] Battal, O. (2012) Investigation of Emotional Intelligence and Parental Attitudes in Primary School Students. Anadolu Journal of Educational Sciences International, 3, 33-51.

[13] Cherry, C., Jane, K. and Julie, M. (2001) Factors Influencing the Educational Performance of Males and Females in their Initiate Destination after Leaving School. A project funded by the Commonwealth Department of Education, Training and Youth Affairs, Deakin University, University of South Australia.

[14] Lee, J. (2001) Interstate Variations in Rural Student's Achievement and Schooling Condition. http://www.ericdigests.org/2002-3/interstate.htm

[15] Agarwal, V.R. (1983) A Study of Reading Ability in Relation to Certain Cognitive and Non-Cognitive Factors. Asian Journal of Psychology and Education, 11, 41-44.

[16] Adeniran, J.A. (1993) The Relative Effectiveness of Lecture and Guided Discovery Methods on Students’ Achievement in Chemistry. M.Ed. Thesis, Ondo State University, Ado-Ekiti, Nigeria. (Unpublished)

[17] Anyadiegwu, J.C. (2012) Communication Competence and General Studies in English in Tertiary Institutions in Nigeria. An International Journal of Language, Literature, and Gender Studies, 1, 44-51.

[18] Owie, I. (1996) Fundamentals of Statistics in Education and the Social Science. United Press, Benin City, Nigeria.

[19] Kolawole, C.O.O. (1998) Linguistic Inputs and Three Methods of Presentation as Determinants of Students’ Achieve- 
ment in Senior Secondary School Essay Writing in Ibadan. PhD Thesis, Department of Teacher Education, University o f Ibadan, Ibadan, Nigeria.

[20] Kolawole, C.O.O. and Dele, A. (2002) Anexamination of the National Policy of Language Education in Nigeria and Its Implications for the Teaching and Learning of the English Language. Ibadan Journal of Education Studies, 2, 12-20.

[21] Ivowi, U.M.O., Okebukola, P.A.O., Oludotun, J.S.O. and Akpan, B.B. (1992) Raising the Standard of Performance in Public Examinations in Science, Technology and Mathematics. Stan Position Paper No. 4.

[22] Olanipekun, S.S., Garuba, I.A. and Mohammed, Y.K. (2014) The Relationship between Students' Academic Performance in General English and Vocational Education Courses. American Association for Science and Technology, International Journal of Modern Education, 1, 84-88.

[23] Akinsolu, A.O. (2010) Teachers and Students’ Academic Performance in Nigeria Secondary Schools: Implications for Planning. Florida Journal of Educational Administration and Policy, 3, 86-103.

[24] Karthigeyen, K. and Nirmala, K. (2012) Academic Achievement in English: An Analysis through Gender Lens. MIER Journal of Educational Studies, Trends and Practices, 2, 144-157.

[25] Harker, R. (2000) Achievement, Gender, the Single Sex Co-Education Debate. British Journal of Sociology of Education, 21, 203-218. http://dx.doi.org/10.1080/713655349

[26] Okeke, E.A. (1993) The Impact of Expository and guided Discovery Approach on JSS Students’ Interest in Mathematics. PhD Thesis, University of Nigeria, Nsukka. (Unpublished)

[27] Ademokoya, J.A. (2007) Onset of Hearing Loss, Gender and Self Concept as Determinants of Academic Achievements in English Language of Students with Hearing Disability in Oyo State, Nigeria. Essays in Education, 22, 65-75.

[28] Olanipekun, S.S. (2013) Appraisal of Nigerian Senior Secondary School's English Language Curriculum in the Light of Modern Curriculum. Advances in Arts, Social Sciences and Education Research, 3, 527-532.

[29] Olanipekun, S.S. and Zaku, J.A. (2013) Gender Analysis of Students’ Entry Qualification in English Language in Colleges of Education in Kwara State. International Journal of Secondary Education, 1, 23-25. http://dx.doi.org/10.11648/j.ijsedu.20130105.12

[30] Federal Republic of Nigeria (2012) Minimum standards for NCE Teachers, General Education. National Commission for Colleges of Education (NCCE), Abuja, Nigeria. 